\title{
CLINICAL AND HISTOPATHOLOGICAL EVALUATION OF TAIL NECROSIS IN SOME FARM ANIMALS
}

\author{
Abdel-Wahed, R. E. ${ }^{*}$ and El-Sayad G. A. ** \\ * Dept. Surgery, Fac. Vet. Med. Alex. Univ. \\ ** Dept. Surgery, Fac. Vet. Med. Tanata Univ.
}

\begin{abstract}
The tail in domestic animals has great and important functions necessary for their life. Tail affections varied between congenital and acquired affections. The most common recorded acquired affection is the tail necrosis.As this affection was lack in histopathological study and there is no literatures explain this subject, the aim of this investigation was to evaluate the clinical, radiographical and histopathological findings of the tail necrosis in some farm animals. One hundred and thirty affected tails in different animal species were recorded in this study. Tail affections were classified according to clinical and radiographic examination. Results and conclusion: Tail necrosis proved to be the most common acquired tail affections (41.53\%) and of breed suscepti-bility especially in buffaloes. Histopathological examinations were helpful in explaining and clarifying all of the clinical and radiographical findings, specially alopecia, hyperkeratinization, inflammation, bone resorption, and paralysis. Partial amputation of the tail was found to be the accurate method of treatment of tail necrosis in farm animals.
\end{abstract}

\section{INTRODUCTION}

The tail in domestic animals has great and important functions necessary for their life. Many functions of the tail may give an idea about the importance of this organ (Sanson, 1969 and Misk, et. al.,1984). Tail affections varied between congenital and acquired affections. The recorded 
congenital affections included anury, bracyury, wry tail, polyury, and luxation of the tail. Meanwhile the recorded acquired affections included tail necrosis, different varieties of wounds, tail fracture, tumours, and tail paralysis (Barakat et al., 1960, Penny and Hill, 1974, Chrisman, 1982, O'Connor, 1980, Misk et al., 1984, and Aziz, 1990). Tail necrosis is the most prevalent and common acquired tail affections among domestic animals (Barakat et al., 1960 and Bertocchi et al., 1973). Tail arrada is a synonym for tail necrosis in buffaloes as mentioned by El-Mekkawi (1958)and Fouad et al.(1984).Incidence of tail necrosis among domestic animals varied between species. It is clear and common in buffaloes, especially in young ages (Barakat et al., 1960 and Aziz, 1990). It was also recorded in horses (Gohar et al., 1988).

The aim of the present investigation is to consider the incidence of tail necrosis among domestic animals concerning the clinical,radiographic and histopathologic findings. As this affection was lack in histopathological study and there is no literatures explain this subject as well as evaluating the different methods of treatment.

\section{MATERIALS AND METHODS}

\section{1- Clinical Examination:}

A total number of(130)animals suffering from different surgical tail affections were presented to the veterinary hospitals of Fac.Vet.Med. At Edfina and Kafr El-Sheikh or collected from private clinics(Table 1).Each case was subjected to clinical examination, differential diagnosis, and then to the possible treatment. Special attention was given to those animals suffering from tail necrosis (54 cases). Treatment of tail necrosis was carried out by two methods; the first one was by partial amputation of the affected part of the tail under the effect of caudal epidural analgesia using 
$2 \%$ xylocaine Hcl. the second method was by dipping of the affected part of the tail into $10 \%$ formalin.

Table(1):Showing the distribution of the tail affections among the recorded cases.

\begin{tabular}{|c|c|c|c|c|c|}
\hline \multirow[b]{2}{*}{ Animals } & \multicolumn{5}{|c|}{ Tail affections } \\
\hline & Necrosis & Wounds & Tumors & Fracture & Total \\
\hline Buffaloes: & 46 & 2 & 3 & 2 & 53 \\
\hline Buffalo Cows & 28 & - & - & - & - \\
\hline Buffalo Calves & 18 & - & - & - & - \\
\hline Cattle & 4 & 6 & 4 & 3 & 17 \\
\hline Horse & 0 & 10 & 2 & 0 & 12 \\
\hline Donkey & 3 & 11 & 6 & 1 & 21 \\
\hline Camel & 1 & 2 & 0 & 0 & 3 \\
\hline Dog & 0 & 2 & 3 & 0 & 5 \\
\hline Sheep & 0 & 14 & 5 & 0 & 19 \\
\hline Total & 54 & 47 & 23 & 6 & 130 \\
\hline
\end{tabular}

\section{2- Radiographic Examination:}

Radiographic examination of normal tail and cases of tail affections, especially tail necrosis, was performed using plain radiography according to the techniques described by Lavin (1999).

\section{3- Histopathological Examination:}

For histopathologic studies, fresh small specimens $(1.5 \times 0.5 \times 0.5 \mathrm{~cm})$ from the affected area of the tail after amputation were taken and fixed in $10 \%$ neutral buffered formalin. These specimens were processed through the conventional paraffin embedding technique(dehydration in ascending grades of ethanol, clearing in different changes in xylene then embedding 
in paraffin at $60^{\circ} \mathrm{C}$ ). Thereafter, the specimens were blocked in paraffin and cut into 5 micron thick sections which were stained with Hematoxylin and Eosin (H\&E) according to the method described by Culling (1983).

\section{RESULTS}

\section{1- Clinical Findings:}

The total number of the affected animals with different tail affections in this study was 130 animal and the results revealed that, 54 (41.53\%) animals, representing nearly all species, were found to be affected with tail necrosis. These cases were distributed as (28) in buffalo cows, representing $51.85 \%$ of the total cases of the tail necrosis;(18)in buffalo calves, representing $33.33 \%$; (4) in cows, representing $7.4 \%$; (3) in donkeys, representing 5,55\% ; and one case in a camel,representing $1.85 \%$ (Table,2).

Table (2): Showing the incidence of tail necrosis in farm animals

\begin{tabular}{|c|c|c|}
\hline \multirow[b]{2}{*}{ Animals } & \multicolumn{2}{|c|}{ Tail Necrosis } \\
\hline & No. & $\%$ \\
\hline Buffaloes: & 46 & 85.18 \\
\hline Buffalo Cows & 28 & 51.85 \\
\hline Buffalo Calves & 18 & 33.33 \\
\hline Cattle & 4 & 7.4 \\
\hline Horse & 0 & 0 \\
\hline Donkey & 3 & 5.55 \\
\hline Camel & 1 & 1.85 \\
\hline Sheep & 0 & 0 \\
\hline Total & 54 & \\
\hline
\end{tabular}

Clinical examination of the involved tails revealed one or more of the following features:

Alopecia, in the free end of the tail (Fig., 1a) or involving the most lower part of the tail(Fig., 1b).Alopecia was encountered associated with or without inflammatory signs (Fig.,1c).Thickening and hyperkeratinization of the distal end of the tail associated with fissures in the distal point and/or few centimeters from the end of the tail (Fig., 2). Paralysis of the lower 
end of the tail was evident, characterized by loss of sensation following pinprick test and coldness in palpation.

The treatments of tail necrosis in this study were achieved by two methods; the first one was by partial amputation of the affected part of the tail which proved beneficial than the other trial.Unsatisfactory results were obtained when dipping of the tail in $10 \%$ formalin was used, in which, reapplication was needed two or three times and some of the treated cases were recurrent. In spite of the amputation was very efficient in this study, two buffalo cases were recurrent.

\section{2- Radiographical Findings:}

The radiographic findings of the normal tail showed coccygeal vertrae of suitable radiodensity, with clear vertebral arch, spinous process and regular intervertebral spaces. Length of the free end of the tail from coccgeal vertebrae was fixed according to each species.

Plain radiography of the affected tails showed increase in the length of the free portion of the tail from coccygeal vertebrae, decreased radiodensity of the coccygeal vertebrae (Fig., 3a\&b), as well as increased and irregular intervertebral spaces (Fig., 3c\&d).

\section{3- Histopathological Findings:}

Microscopical examination revealed that, the uppermost layer of the epidermis showed extensive diffuse hyperkeratosis where the stratum corneum appeared thick with absence of the nuclei(Fig.4a).In some areas, the stratum spinosum exhibited hyperplasia of the prickl cells leading to presence of papillary epidermal structures infiltrated deeply into the dermis with intact basement membrane.Moreover,within these hyperplastic epidermal structures embedded spherical keratin structures were seen(Fig.4b). Occasionally,both the deep layer of the epidermis and the dermis showed focal coagulative necrosis(Fig. 5a).In addition,some hair follicles showed complete coagulative necrosis with infiltration of leukocytes within and around the necrotic follicles (Fig. 5b).Furthermore, the deep dermis exhi- 
bited severe congestion, hemorrhage and mild leukocytic infiltration(Figs. $6 a \& b)$. The myofibers of the muscular layer exhibited both Zenker's necrosis (Fig. 7a) as well as fibrosis (Fig. 7b).The free end of the tail was free from coccygeal vertebrae where the bone was completely lysed and replaced by leukocytes almost exclusively macrophages (Fig. 7c).

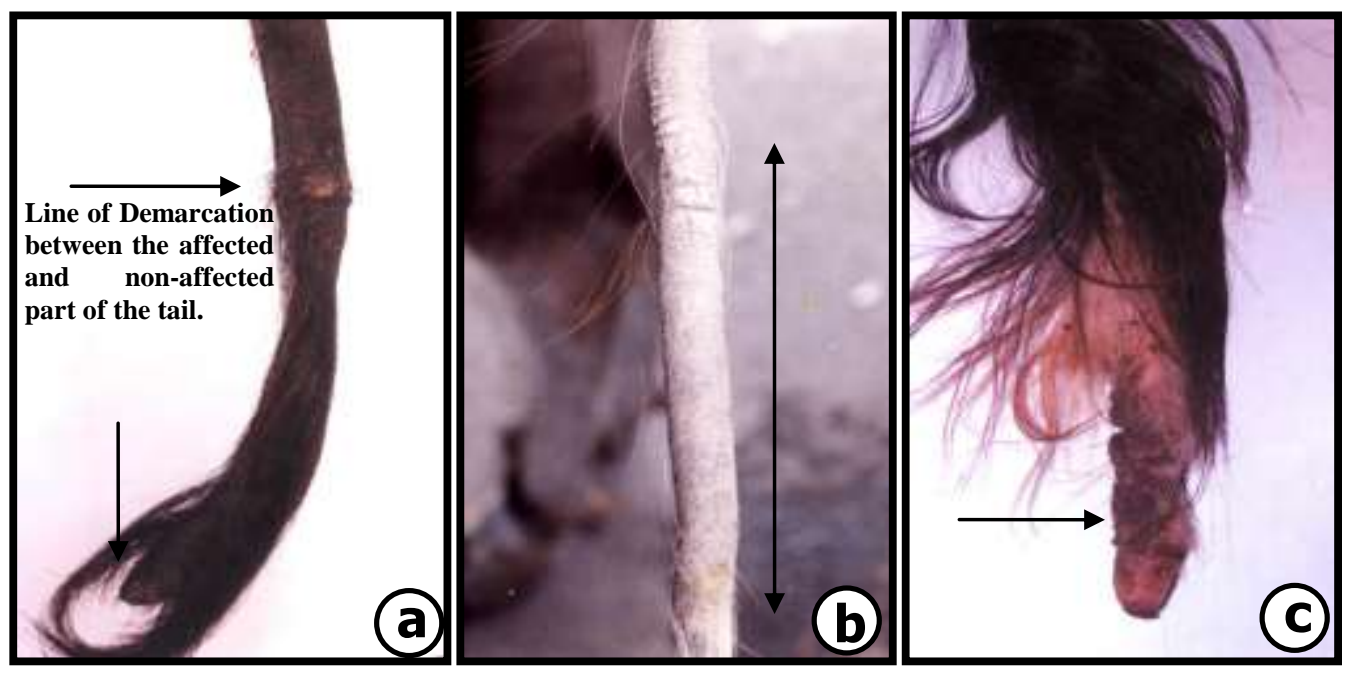

Fig. (1): Photographs showing alopecia in: the free end of the tail (a), alopecia involving the lower part of it (b) and associated with inflammatory signs (c). (Arrows). 
Fig. (2): A photograph showing Fissures and thickening few centimeters from the distal end of the tail.
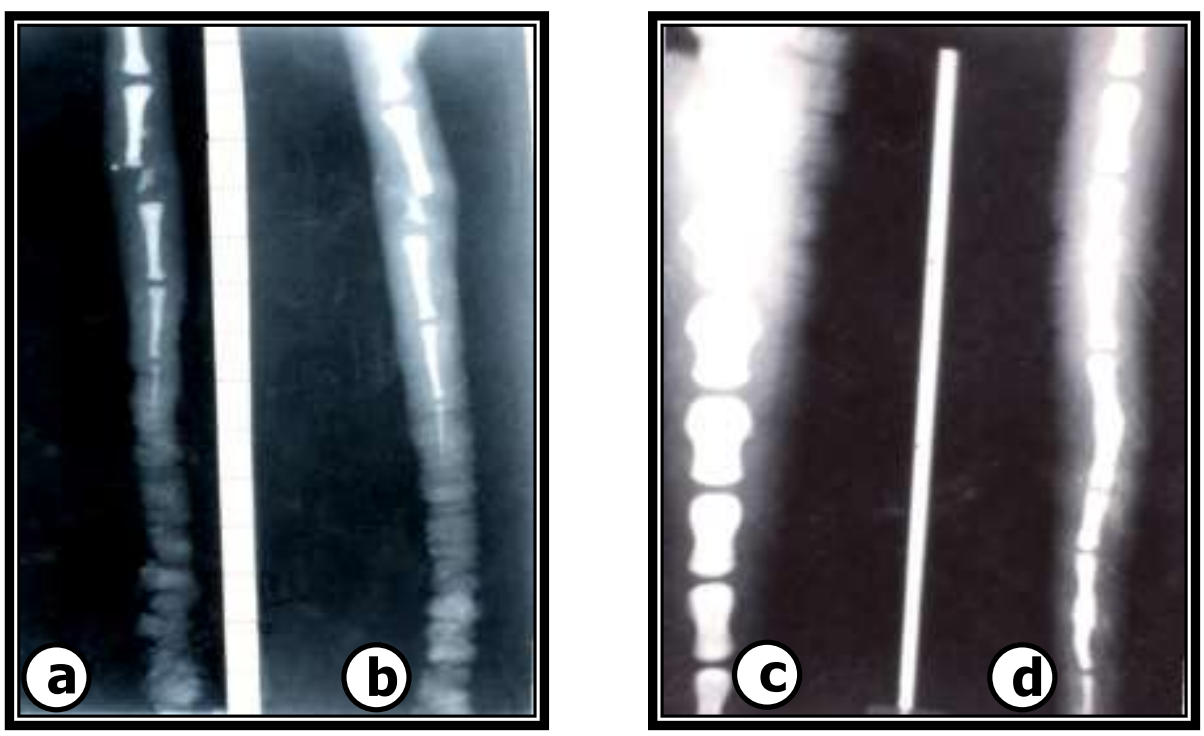

Fig. (3): Radiographs showing a necrosed buffalo tail characterized by increased length of the free portion of the tail from coccygeal vertebrae with decreased radiodensity of the terminal vertebrae $(\mathrm{a} \& \mathrm{~b})$ and irregular intervertebral spaces (c\&d).
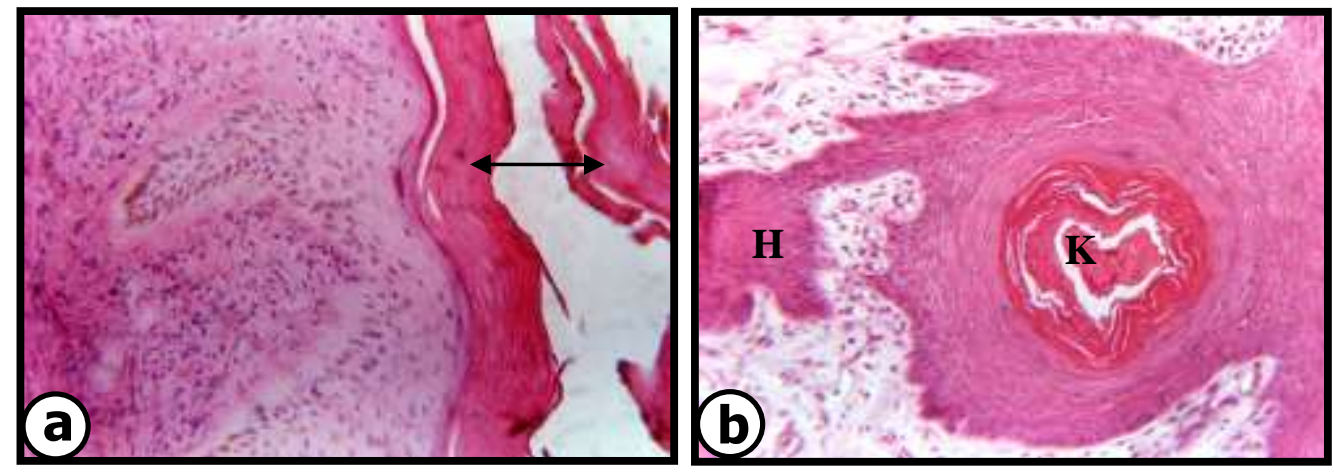

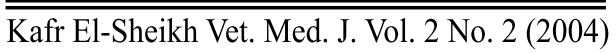


Fig.(4): Photomicrographs showing hyperkeratosis of the stratum cornium of the epidermis. Note thickened layer with absence of the nucleus (Arrow) H\&E (X160) (a).Hyperplasia of stratum cornium forming folds deeply embedded into the dermis $(\mathrm{H})$ with keratinous structures within the epidermis (K). H \& E (X 250) (b).
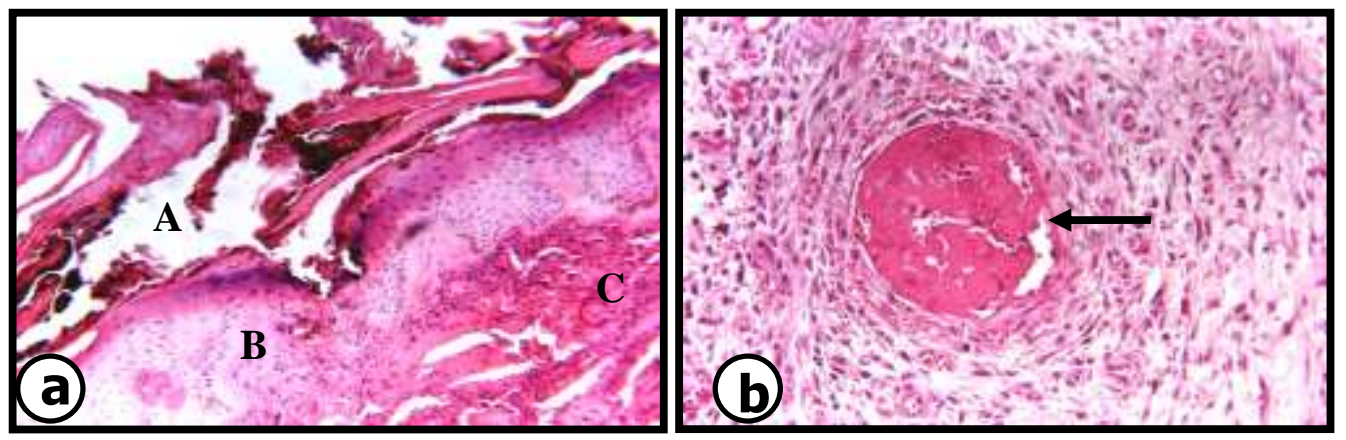

Fig.(5): Photomicrographs showing severe hyperkeratosis (A) with coagulative necrosis of the deep epidermis (B) and dermis (C). H \& E (X 160) (a). A hair follicle showing complete coagulative necrosis (arrow) with infiltration of leukocytes within and around the follicle and presence of dilated capillaries around the follicle representing the inflammatory reaction. H \& E (X 160p) (b).
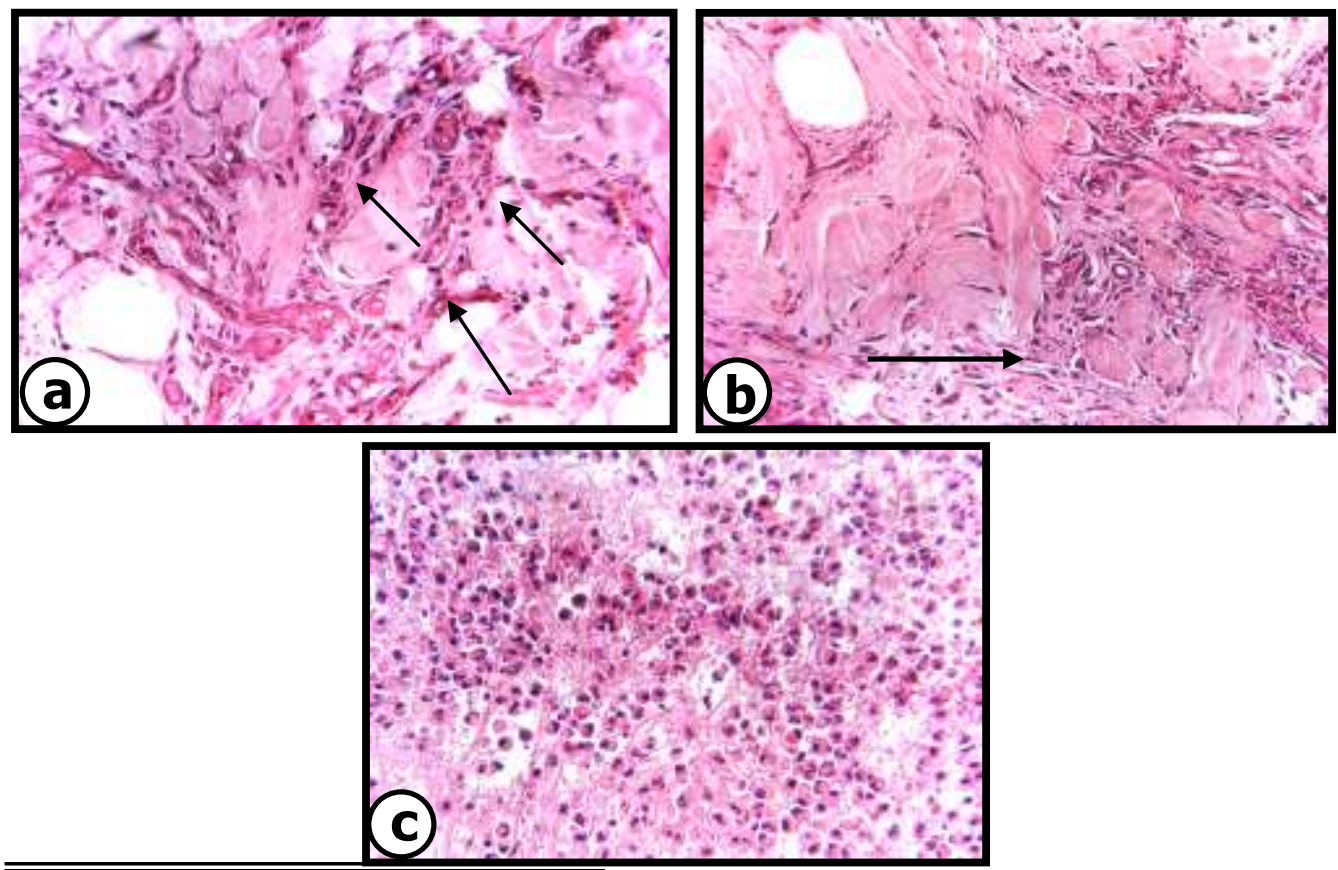

Kafr El-Sheikh Vet. Med. J. Vol. 2 No. 2 (2004) 
Fig.(6):Photomicrographs showing Zenker's necrosis of the myofibers(Arrows) with leukocytic infiltration. H \& E (X 160) (a), Severe focal fibrosis of the muscular layer[(arrow), H \& E (X 160) (b) and severe diffuse infiltration of leukocytes, primarily macrophages replacing the lysed coccygeal vertebrae. H \& E (X 400) (c).

\section{DISCUSSION}

Tail affections among farm animals varied between acquired and congenital and the tail necrosis is one of the acquired affections. The study under investigation revealed that, tail necrosis was recognized in all farm animals with variable incidence percentage. Incidence was high in buffaloes $(\mathbf{8 5 \%})$, especially in buffalo cows. The condition was recorded in buffaloes by (El-Mekkawi, 1958 and Barakat et al., 1960); in fattening bull calves (Bertochi, et. al., 1973); in ruminants (Fouad et al., 1984); in horses (Gohar et al., 1988); in calves (El-Maghraby, 1988) and in donkeys, buffaloes and cattle (Misk et al., 1995).

The increased incidence of tail necrosis in buffalo calves was attributed to the nutritional disorders, especially in cases of persistent diarrhea, where the condition is commonly noticed. This result was also obtained by Aziz (1990).

Concerning the lesion characters, careful clinical examination proved to be necessary to confirm the condition (Smith, 2002). There might be one or more specific lesions could be considered diagnostic for tail necrosis. Alopecia, thickening and hyperkeratinization, as well as paralysis of the free end of the tail were the prevalent signs of tail necrosis.Radiography was valuable to confirm such findings.

Misk et al. (1995) found that, the most important feature stated radiographically was the presence of free portion from coccygeal vertebrae, at the end of the tail. This result is in agreement with our plain radiographic findings. 
Histopathoogical examination, herein, was of value to explain and discuss most of the clinical and radiographic features. Increased free portion of the end of the tail could be attributed to vertebral lyses, as the bone was completely resorbed and replaced by leukocytes. Thickening and hard texture are due to fibrosis and extensive diffuse hyperkeratosis of the uppermost layer of the epidermis, where the stratum corneum appeared thick with absence of the nuclei. Hargis (1995) and White and Evans (2002) recognized this type of hyperkeratosis as parakeratosis. Carlton and McGavin, (1995) clarify that; this hyperkeratosis is common, non specific responses to chronic stimuli.

The dermis exhibited congestion, hemorrhage, and mild leukocytic infiltration, exhibiting the darkness and inflammatory signs. Cooper (2002) confirmed these facts when recorded that morphological changes that recognized microscopically are, however, the result of degradation of the cell content. As necrosis may be discernable at the gross level, it should be appreciated only at the microscopic level(Slauson and Cooper, 2002).

Paralysis of the tail end could be attributed to necrosis. Focal and complete coagulative necrosis in skin and hair follicles, respectively,may develop due to external gross physical violence or internal endogenous causes, and to which coldness and loss of sensation in involved area could be attributed (Cottran et al., 1999).

Following partial amputation of the necrosed tail,recovery occurred without complications and healing achieved favorably within 10 days by first intention.Several literatures agreed the treatment by amputation as the only and ideal treatment for such affection. Recurrence of the affection after amputation was recorded in two buffalo cases only; this could be attributed to the real cause which may be nutritional or incomplete removal of the affected part of the tail. 
Meanwhile, using of $10 \%$ formalin dipping necessitated re-application of the dipping two or three times. This method of treatment was conducted only according to owner request who refused the amputation.

\section{REFERENCES}

- Aziz MS(1990): Comparative and applied surgical anatomy of the tail with special reference to its surgical affections in some domestic anim-als. M.V.Sc. Thesis (Surgery), Assiut Univ., Egypt.

- Barakat MZ, Wahby AM and Abd-Alla A (1960): Necrosis of the tail in the buffalo, a deficiency disease. Brit. Vet. J., 116 (4): 151-155.

- Bertocchi D, Franciosi C,Mondini S and Zoboli C (1973): Necrosis of the tail of the fattening bull calf. Epidemiological clinical and statis-tical observations. Atti della societa Italino di buiatria, 5: 183-191.

- Carlton WW and McGavin MD(1995):Thomson's Special Veterinary Pathology. $2^{\text {nd }}$. Ed., Mosby, Inc.

- Chrisman CL (1982): Problems in small animal neurology. Lea and Febiger. Philadelphia.

- Cooper BJ (2002): Diseases at the cellular level. In: Mechanisms of disease. A textbook of comparative general pathology. $3^{\text {rd }}$ Ed., Mosby, Inc.

- Cottran RS,Kumar V and Collins T(1999):Robbins Pathologic basis of Disease. $6^{\text {th }}$ Ed., W.B. Sanders Co.

- Culling CF (1983): Handbook of histopathological and histochemical techniques. $3^{\text {rd }}$ Ed., Butterworths. London.

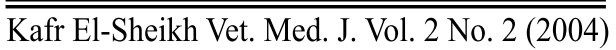


- El-Maghraby HM (1988): Studies on surgical affections of calves at Kaliobia Governorate. M.V. Sc. Thesis, Zagazig Univ., Benha Branch, Egypt.

- El-Mekkawi FM (1958): Tail necrosis in buffaloes. Vet. J., Gizza, 5: 89-106.

- Fouad KA, Misk NA and Kassem MM (1984): Some surgical affec-tions in the ruminants. Assiut Vet. Med. J., 11: 183-187.

- Gohar HM, Abdel-Hamid MA,Ahmed AS and Ibrahim IM (1988): Tail necrois in the horse. Assuit Vet. Med. J., 19 (38): 92-95.

- Hargis AH(1995):Integumentary system (461). In:Thomson's Special Veterinary Pathology. $2^{\text {nd }}$ Ed., Mosby, Inc.

- Lavin LM (1999): Radiography in veterinary technology. $2^{\text {nd }}$ Ed.,W.B. Saunders Co.

- Misk NA,Bhargava AK and Sing CR (1984): Congenital sacral defo-rmity, tailessness and atresia ani in a calf. Agri. Practice, 5 (7): 38-46.

- Misk NA, Seleim MA and Aziz MS (1995): Morphoanatomical and radiographic studies on the tail on some domestic animals.

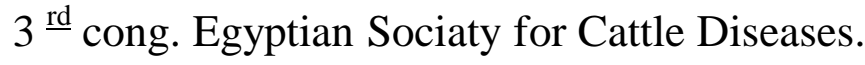

- Misk NA, Seleim MA and Aziz MS (1995): Surgical affections of the tail in some farm animals. $3^{\text {rd }}$ cong.Egyptian Sociaty for Cattle Diseases.

- O'Connor, J. (1980): Dollar's veterinary surgery. $4^{\text {th }}$ Ed., Bailliere Tindal and cox, London. 
- Penny RH and Hill FW(1974): Obsevations of some conditions in pigs at the abattoir with particular reference to tail bitting. Vet. Rec.,94 (9): 174-180.

- Sanson, B.F. (1969): Variations in the relative cortical mass of tail bones of cows during pregnancy and lactation. British Vet. J., 125 (9): 454-457.

- Slauson DO and Cooper BJ (2002): Mechanisms of disease. A textb-ook of comparative general pathology. $3^{\text {rd }}$ Ed., Mosby, Inc.

- Smith BP (2002): Large animal internal medicine. $3^{\text {rd }}$ Ed., Mosby, Inc.

- White SD and Evans AG (2002): Alterations in the skin. In: Large animal internal medicine. $3^{\text {rd }}$ Ed., Mosby, Inc.

$$
\begin{aligned}
& \text { التقييم الإكلينيكي و الهستوباثولوجي لتنكرز الذيل في بعض حيوانات المزرعة } \\
& \text { رمضان السيد عبد الواحد* و جمال أحمد الصياد * } \\
& \text { *قسم الجراحة كلية الطب البيطرى بادفينا جامعة الأسكندرية" } \\
& \text { "قسم الجراحة كلية الطب البيطرى بكفر الثيخ جامعة طنطا }
\end{aligned}
$$

يعد الذيل في الحيوانات من الأعضاء الهامة لما له من وظائف ضرورية لحياتهم. تتعدد إصابات الذيل ما بين العيوب الخلقية و الإصابات المكتسبة. و نظرا لأن تتكرز الذيل لم تحظى بدراسة هستوباثولوجية وافية فقد كان الهدف من هذه الدراسة هو عمل تقييم للظواهر الإكلينيكية والهستوبانولوجية لهذه الإصابة في حيوانات المزرعة. نم إجراء هذه الدراسة علي عدد 130 ذيل مصاب من مختلف الفصائل الحيوانية. تم تسجيلها فى مستثفى كلية الطب البيطرى بادفينا 
وكفر الثيخ وكذلك من بعض العيادات الخاصة. نم تصنيف ونتخيص الإصابات اعتمادا علي الفحص الإكلينيكي و الإشعاعي.

أوضحت الدراسة أن نتكرز الذيل هي فعلا أكثر إصابات الذيل شيوعا فقد منلت 42(41.53\%) من مجمل إصابات الذيل وأنه يوجد ارتباط وثيق لهذه الإصابة مع الجاموس وخاصة الإناث. كما أوضحت أن الفحص الهستوباثولوجى له دور كبير وهام في تأكيد و تفسير العديد من الظواهر الإكلينيكية و الإشعاعية منل اختقاء الثعر والفقرات في منطقة الإصابة والالتهابات والخشونة والثنل. كما وجد أن قطع الجزء المصاب من الذيل هو أضمن الطرق العلاجية لهذه الظاهرة في حيوانات المزرعة بالرغم من عودة ظهور الإصابة فى حالثين فقط من الجاموس وقد أرجع ذلك إلى احتمالية أن هناك سبب غذائى أو عدم استئصال الجزء المصاب كاملا. 